\title{
Teknik Analisis Sisa Manusia
}

\section{Harry Widianto}

Keywords: bones, homo, analysis, practices, method, theory, identification

\section{How to Cite:}

Widianto, H. (2000). Teknik Analisis Sisa Manusia. Berkala Arkeologi, 20(1), 15-25. https://doi.org/10.30883/jba.v20i1.803

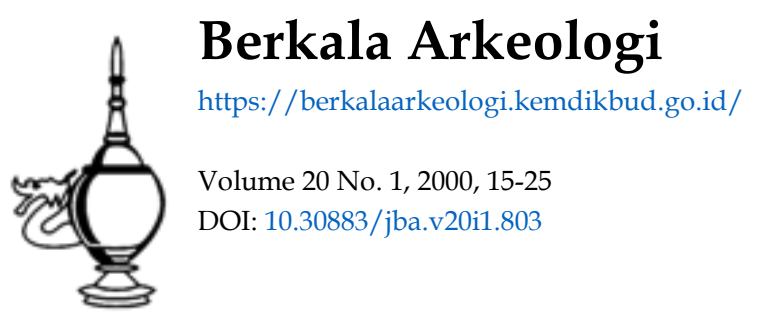

\section{c) (1)(2)}

This work is licensed under a Creative Commons Attribution-NonCommercial-ShareAlike 4.0 International License. 


\title{
TEKNIK ANALISIS SISA MANUSIA
}

\author{
Harry Widianto \\ (Balai Arkeologi Yogyakarta)
}

Dalam operasional penelitian arkeologi di lapangan, baik dalam survei maupun ekskavasi, tidak jarang ditemukan sisa rangka manusia, yang dalam konteks data arkeologi merupakan bagian dari jenis data ekofak. Apabila diaplikasikan pada jenis situs di Indonesia, situs-situs yang mempunyai potensi dalam memberikan data tentang sisa manusia adalah situs-situs hominid dari Kala Plestosen dan situs hunian gua maupun situs penguburan prasejarah dari Kala Holosen. Pengalaman penemuan sisa manusia selama ini menunjukkan bahwa situs-situs hominid dari Kala Plestosen antara 1.5 hingga 0.3 juta tahun lalu secara tunggal didominasi oleh takson Homo erectus (misalnya di Trinil, Sangiran, Ngandong, Perning, Kedungbrubus), sementara sisa manusia dari akhir Kala Plestosen hingga masa kini lebih didominasi oleh Homo sapiens. Dalam jalur evolutif yang secara aman dapat diterima, diperoleh pemahaman bahwa Homo sapiens telah tersebar secara luas di berbagai permukaan bumi paling tidak sekitar 40.000 tahun lalu. Bukti-bukti dari berbagai situs hunian gua di Asia Tenggara pada periode akhir Kala Plestosen hingga transisi Plestosen-Holosen lebih mengacu pada karakter Austromelanesid dan Mongoloid (periksa misalnya Jacob, 1967), dan di lain pihak -sebagai misal-- ekskavasi yang dilaksanakan oleh Pusat Penelitian Arkeologi Nasional di Song Keplek dan Gua Braholo akhir-akhir ini telah memberikan data baru tentang penemuan 8 individu sisa manusia pendukung hunian gua pada awal Kala Holosen berciri Austromelanesid (Widianto, 1999a), yang diikuti oleh temuan sebuah rangka manusia relatif bagus di Song Keplek berciri Mongoloid (Widianto, 1999b; Handini dan Widianto, 1998). Riwayat penemuan menunjukkan bahwa Homo erectus dan Homo sapiens merupakan dua spesies produk evolusi dari genus Homo yang mewarnai penemuan-penemuan sisa manusia di Indonesia.

\section{A. Homo erectus vs Homo sapiens}

Dalam evolusi manusia, bagian yang paling signifikan mengalami perubahan adalah bagian kepala manusia. Hal ini disebabkan oleh perkembangan otak yang terjadi, yang berimplikasi secara kuat pada perkembangan bentuk tengkorak. Bertambahnya volume otak merupakan suatu arah yang tidak berbalik (irreversible). Dalam prosesnya, perkembangan tersebut akan berimplikasi terhadap 2 aspek kranio-fasial : pergeseran occipital (dan juga muka) ke arah bawah, disertai dengan penyempitan kedua sisi lateral (Dellatre et Fenart, 1960). Akibatnya, kontur kranial secara anteroposterior maupun secara transversal akan semakin lebih tinggi dan bundar (Widianto, 1999c), dengan jarak antara 2 asterion yang semakin tereduksi. Proses evolutif seperti 
inilah yang sangat jelas terlihat antara Homo erectus dan Homo sapiens, dengan indikator antara lain sebagai berikut : panjang dan lebar kranial semakin tereduksi, prognatisma semakin berkurang, kening semakin tegak, lebar maksimal kranial bergeser dari temporal ke perietal, linea temporalis semakin bergerak ke bawah menjauhi garis median sagittal, sudut occipital semakin besar, planum occipitalis semakin lebar dibandingkan dengan planum nuchalis, foramen magnum semakin bergerak ke arah depan, dan perkembangan superstruktur kranial semakin mengalami grasilisasi. Data paleoanthropologis menunjukkan bahwa bagian infra-kranial (anggota badan) sangat sedikit menunjukkan perubahan, sehingga femur Homo erectus dari Trinil (Trinil 3) misalnya, menunjukkan banyak kesamaan dengan femur Homo sapiens. Beberapa karakter morfologis yang membedakan Homo erectus dari Homo sapiens berdasarkan karakter evolutif dan perkembangan superstruktur kranial antara lain adalah sebagai berikut :

Homo erectus

tengkorak panjang dan rendah

lebar maksimal kranial di bagian temporal

kapasitas cranial $700-1100 \mathrm{cc}$

prognathisme menonjol

frontal datar

tengkorak tebal, terutama di

bregma, asterion, dan inion

torus supra orbitalis menonjol

line a temporalis pada posisi tinggi mendekati sutura sagittalis

mempunyai torus angularis

sudut runcing di bagian occipital

torus occipitalis menonjol

planum occipitalis lebih sempit diban-

dingkan planum nuchalis

inion dan opisthocranion terletak

pada titik yang sama

\section{Homo sapiens}

- pendek dan tinggi

- di bagian parietal

$-1200--2000 \mathrm{cc}$

- lemah

- tegak

- tipis

- absen

- pada posisi rendah, mendeka-

ti sutura parieto-temporalis

- absen

- sangat tumpul/bundar

- sangat lemah

- lebih lebar

- terpisah sekitar 2 -- $3 \mathrm{~cm}$ 
Didasarkan pada karakter morfologis yang melekat pada kedua spesies di atas, tampak jelas bahwa Homo erectus sangat berbeda dengan Homo sapiens, sehingga proses indentifikasi untuk membedakan keduanya cukup mudah untuk dilakukan. Di lain pihak, perolehan data Homo erectus secara kuantitas juga sangat sedikit, dan secara kualitas lebih banyak berupa atap tengkorak (dan fragmennya) maupun rahang bawah (dan fragmennya). Selanjutnya, dihadapkan pada anggapan tentang status Homo erectus yang menempati posisi evolutif setingkat sebelum mencapai Homo sapiens, maka segala aspek yang melekat pada temuan Homo erectus tampaknya harus ditangani secara lebih detil dan lebih khusus analisisnya, dengan parameter analisis yang untuk hal-hal tertentu cukup berbeda dengan parameter yang diperlakukan terhadap sisa manusia dalam konteks Homo sapiens. Oleh karena itu, untuk mendapatkan perangkat dan teknik analisis sisa manusia secara global seperti yang dikehendaki oleh pertemuan ini, maka fokus bahasan (dan juga struktur data base) yang akan saya uraikan di sini hanyalah menyangkut teknik analisis sisa manusia dari tingkatan takson Homo sapiens saja, sebagai jenis data yang paling sering ditemukan dalam penelitian-penelitian arkeologis selama ini. Titik berat bahasan akan diberikan pada lingkup analisis yang mencakup : komponen anatomis tersisa, identifikasi jenis kelamin, identifikasi usia individu, dan identifikasi ras.

\section{B. Komponen Anatomis Tersisa}

Langkah pertama yang harus dilakukan dalam analisis sisa manusia adalah memberikan gambaran tentang materi data yang tersisa. Gambaran ini harus memberikan informasi yang cukup lengkap tentang komponen anatomis yang akan dianalisis secara lebih lanjut, yang sebaiknya dimulai dari bagian kepala hingga bagian kaki. Bagian kepala dibedakan dalam variabel cranium, calvarium, calvaria, dan calva. Secara lebih detil, diberikan pula material tersisa dari tulang kepala (frontal, parietal kanan-kiri, temporal kanan-kiri, occipital, dan dasar tengkorak), dengan mulai mencantumkan ciri-ciri morfologis yang masih dapat diamati (misalnya pars orbitalis, linea temporalis, dan sebagainya). Masih dalam konteks bagian kepala ini, diberikan pula pemerian material tersisa dan aspek morfologis yang dapat diamati pada bagian rahang beserta gigi-geliginya, baik rahang atas (maxilla) maupun rahang bawah (mandibula). Selanjutnya, diberikan uraian secara lengkap mengenai material tersisa pada bagian infra tengkorak, mulai tulang leher (yang menyambung hingga sacrum), hingga anggota badan atas dan anggota badan bawah, sampai kepada 
phalanx distalnya. Dalam identifikasi material tersisa perlu kiranya diberikan kepastian bagian-bagian yang hilang (atau masih tersisa) bagia jenis-jenis tulang yang jumlahnya lebih dari satu, misalnya vertebrae, ossa metacarpal, metatarsal, maupun phalanx. Perlu ditegaskan : lengkap atau tidak lengkap, tersisa phalanx median jari III kiri, atau tersisa M2 bawah kanan.

\section{Identifikasi Jenis Kelamin}

Jenis kelamin suatu individu dapat didasarkan dengan mengobservasi aspek tengkorak dan tulang pinggul (pelvis). Secara umum, postur individu laki-laki lebih kekar dibandingkan dengan individu perempuan. Demikian pula ukuran tengkoraknya lebih panjang, lebih lebar, dan lebih tinggi, dengan kapasitas tengkorak yang lebih besar pula (laki-laki : sekitar $1.400 \mathrm{cc}$, perempuan sekitar $1.250 \mathrm{cc}$ ). Konotasi seperti ini juga selaras dengan ukuran gigi-geiliginya. Berikut ini akan diuraikan penentuan jenis kelamin berdasarkan karakter morfologis tengkorak dan tulang pinggul.

\section{Berdasarkan karakter morfologis tengkorak}

Pada individu laki-laki, dimensi muka relatif lebih besar dibandingkan dengan individu perem-puan : dengan parameter ukuran tinggi muka (prosthion-nasion), lebar bizygomaticus dan panjang muka (basion-prosthion). Aspek superstruktur pada individu laki-laki lebih berkembang diban-dingkan dengan individu perempuan : glabella dan arcus superciliaris lebih menonjol, processus mastoideus lebih besar dan lebih tinggi, relief muskuler pada planum nuchalis dan protuberus occipitalis externa lebih berkembang. Pada individu laki-laki ini, terlihat bahwa arcus zygomati-cus lebih tebal dan tinggi dibandingkan dengan perempuan, dengan frontal yang lebih miring dan menunjukkan satu tonjolan frontalis di tengah-tengah kening. Pada individu perempuan, os fron-talis lebih vertikal dan relatif menunjukkan 2 tonjolan frontalis secara lateral. Bentuk orbit pada individu laki-laki adalah persegi dengan margo supra-orbitalis tumpul, sementara pada individu perempuan menunjukkan bentuk orbit bundar dan margo supra-orbitalis lancip. Mengenai penentuan jenis kelamin individu ini dapat dikalkulasikan sebagai berikut : 


\begin{tabular}{|c|c|c|c|c|c|c|c|}
\hline Karakter & $A$ & $\begin{array}{c}\text { Sangat feminin } \\
-2\end{array}$ & $\begin{array}{c}\text { Feminin } \\
-1\end{array}$ & $\begin{array}{l}\text { Transisi } \\
\quad 0\end{array}$ & $\begin{array}{c}\text { Maskulin } \\
+1\end{array}$ & $\begin{array}{c}\text { Sangat maskulin } \\
+2\end{array}$ & $\begin{array}{l}\text { Nilai } \\
\mathbf{A} \times \mathbf{B}=\ldots\end{array}$ \\
\hline Glabella & 3 & Sangat lemah & lemah & cukup & menonjol & sangat menonjol & $3 \times \ldots=$ \\
\hline $\begin{array}{l}\text { Precessus } \\
\text { Inastoideus }\end{array}$ & 3 & Sangat kecil & kecil & cukup & besar & sangat besar & $3 \times \ldots=$ \\
\hline $\begin{array}{l}\text { Relief mnskuler } \\
\text { planum nuchalis }\end{array}$ & 3 & Sangat lemah & lemah & cukup & berkembang & sangat berkembang & $3 \times \ldots=$ \\
\hline Arcus zygomaticus & 3 & $\begin{array}{l}\text { tipis, sangat } \\
\text { rendah }\end{array}$ & $\begin{array}{l}\text { cukup tipis, } \\
\text { rendah }\end{array}$ & $\begin{array}{l}\text { transisi } \\
\text { tinggi }\end{array}$ & $\begin{array}{l}\text { tebal, } \\
\text { sangat tinggi }\end{array}$ & sangat tebal, & $3 \times \ldots=$ \\
\hline $\begin{array}{l}\text { Arcus } \\
\text { superciliaris }\end{array}$ & 2 & sangat lemah & lemah & cukup & menonjol & sangat menonjol & $2 \times \ldots=$ \\
\hline $\begin{array}{l}\text { Tonjolan } \\
\text { frontal }\end{array}$ & 2 & $\begin{array}{l}2 \text { lateral } \\
\text { menonjol }\end{array}$ & $\begin{array}{l}2 \text { lateral } \\
\text { cukup menonjol }\end{array}$ & $\begin{array}{l}\text { transisi } \\
\text { menonjol }\end{array}$ & $\begin{array}{l}1 \text { median } \\
\text { lemah }\end{array}$ & $I$ median & $2 \times \ldots=$ \\
\hline $\begin{array}{l}\text { Protuberus occipi- } \\
\text { talis externa }\end{array}$ & 2 & sangat lemah & lemah & transisi & menonjol & sangat menonjol & $2 \times \ldots=$ \\
\hline $\begin{array}{l}\text { Kemiringan } \\
\text { os frontalis }\end{array}$ & 1 & vertikal & sedikit vertikal & $\begin{array}{l}\text { sedikit } \\
\text { miring }\end{array}$ & miring & sangat miring & $1 \times \ldots=$ \\
\hline $\begin{array}{l}\text { - Bentuk orbit } \\
\text { - Bentuk margo } \\
\text { supra orbitalis }\end{array}$ & 1 & $\begin{array}{l}\text { - sangat bulat } \\
\text { - sangat lancip }\end{array}$ & $\begin{array}{l}\text { - bulat } \\
\text { - Lancip }\end{array}$ & transisi & $\begin{array}{l}\text { - agak persegi } \\
\text { - tumpul }\end{array}$ & $\begin{array}{l}\text { - persegi } \\
\text { - singal tumpul }\end{array}$ & $1 \times \ldots=$ \\
\hline $\begin{array}{l}\text { perempuan } \\
-2-1\end{array}$ & & $\begin{array}{l}\text { laki-laki } \\
+1+2\end{array}$ & & & & & $\Sigma(A \times B)=$ \\
\hline $\begin{array}{l}\text { Jika nilai di atas } \\
\text { Jika nilai di bawah }\end{array}$ & $\begin{array}{l}0 \\
0\end{array}$ & $\begin{array}{l}\text { laki-laki } \\
\text { perempuan }\end{array}$ & & & & & \\
\hline
\end{tabular}

\section{PENENTUAN JENIS KELAMIN BERDASARKAN KARAKTER MORFOLOGIS KRANIAL}


Dibandingkan dengan tulang pinggul laki-laki, tulang pinggul wanita menunjukkan bentuk yang lebih rendah dan lebih lebar. Dimensi ini tidak hanya berlaku untuk tulang pinggul (pelvis) secara keseluruhan, tetapi juga berlaku untuk dimensi dan bentuk tulang terlepas : kedua coxae dan sacrumnya. Sudut di bawah pubis juga lebih terbuka. Lebih besarnya tulang pinggul wanita dibandingkan dengan tulang pinggul laki-laki sangat berhubungan dengan faktor reproduksi, karena secara alamiah telah "di-design" sedemikian rupa untuk menopang pertumbuhan bayi di perut dan memperlancar proses melahirkan.

Selain lebih lebar dan lebih rendah, pelvis perempuan menunjukkan bentuk yang lebih terbuka dibandingkan dengan pelvis laki-laki, dengan cavitas pelvis yang lebih lebar. Di lain pihak, bentuk coxa pada individu perempuan adalah tambun dan lebar, sementara pada individu laki-laki adalah ramping dan ramping (kanan-kiri) dan tinggi (atas-bawah). Ukuran yang lebih lebar pada individu perempuan juga ditunjukkan pada incisura seiatica major, dengan foramen obturatum yang berbentuk bulat.

\section{Identifikasi Usia Individu}

Determinasi usia individu sisa rangka merupakan persoalan yang cukup sulit dilakukan dan menawarkan banyak kesalahan dalam penentuan angka usia yang lebih pasti (Masset, 1982). Implikasinya, usia individu ini -demi amannya sebuah interpretasi tentangnya--cukup dijabarkan dalam angka yang cukup besar kisarannya. Karakter yang dipakai tidak bisa secara persis ditentukan, dan bervariasi menurut pertumbuhan individu tersebut. Tiga parameter yang umum dipakai sebagai penentu usia individu adalah : derajad pertautan (sinostosa) sutura pada tengkorak, erupsi gigi, dan tingkat keausan gigi. Dalam kenyataannya, ketiga parameter observasi ini akan berjalan selaras dan bersama, dalam arti bahwa ketiganya akan mengalami proses perubahan seiring dengan berjalannya usia seseorang.

\section{Derajad pertautan sutura}

Dalam proses pertumbuhan (dari kelahiran hingga kematian), beberapa sutura tertentu pada tengkorak yaitu sutura coronalis, sutura sagittalis, dan sutura lambdoidea mempunyai perubahan yang cukup signifikan dalam perkiraan usia individu tersebut. Sutura tersebut akan mengalami proses : terbuka (anak-anak), rapat (dewasa), dan menghilang (dewasa lanjut). Proses seperti ini yang dicoba untuk menghitung usia individu, dengan pengamatan derajad penghapusan sutura dalam skala Broca (1875) dan mengkalkulasi nilai faktor "S" (sinostosa) oleh Masset (1982). 


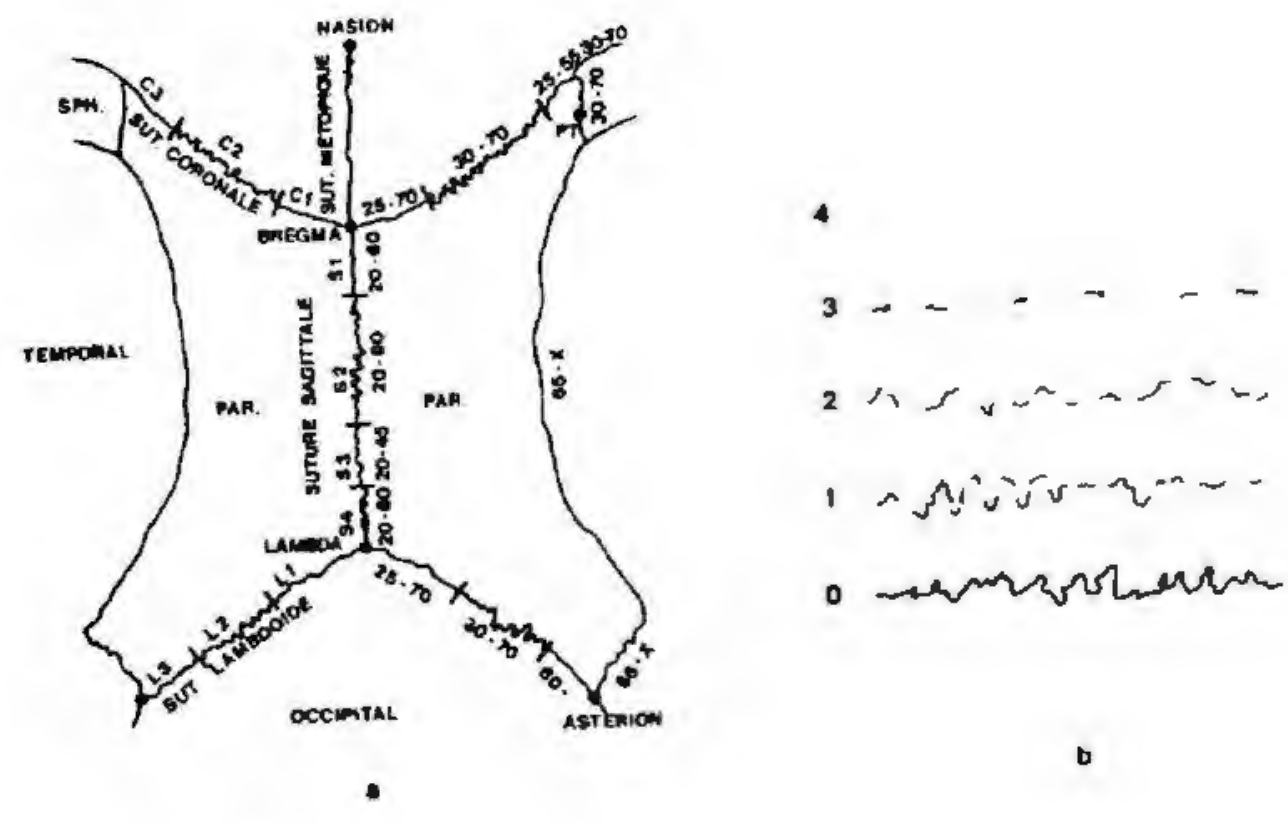

a. segmen dan usia penutupan sutura b. derajad sinostosa (Broca, 1875)

Sutura sagitallis masing-masing sisi terbagi dalam segmen : S1, S2, S3, dan S4. Sutura coronalis terbagi dalam : $\mathrm{C} 1, \mathrm{C} 2$, dan C3. Sementara sutura lambdoidea masing-masing sisi terbagi dalam segmen L1, L2, dan L3. Lima derajad sinostosa yang ditawarkan oleh Broca adalah : sutura terbuka (0), sedikit sinostosa (1), setengah sinostosa (2), tiga perempat sinostosa (4), dan tertutup sempurna (5). Perubahan masing-masing sinostosa ini tidak teratur, segmen $\mathrm{C} 3$ pada obelion akan terhapus pertama kali.

Dengan mengaplikasi nilai pada skala Broca, seluruh segmen sinostosa pada sutura kranial dijumlahkan (akan menghasilkan angka antara 0 hingga 40), dan dibagi 10 untuk mendapatkan nilai " $S$ ". Selanjutnya, usia individu dihitung melalui rumus Masset : Usia $=-4.44 \mathrm{~S}^{2}+22.86 \mathrm{~S}+30.44 \pm 14.76$ (untuk individu laki-laki) $=-2.85 \mathrm{~S}^{2}+16.33 \mathrm{~S}+39.08 \pm 15.5$

(untuk individu perempuan)

\section{Erupsi gigi-geligi}

Penentuan usia individu berdasarkan tingkat crupsi gigi-geligi merupakan teknik penguat, yang sangat efektif dipakai untuk individu anak maupun dewasa sebelum mencapai usia 18 tahun. Hal ini disebabkan oleh erupsinya gigi-geligi (susu dan permenen) dalam periode tertentu secara teratur, dan dalam teorinya, gigi terakhir yang akan muncul adalah geraham ketiga (M3). Molar ketiga ini akan muncul paling tidak setelah seseorang mencapai usia 18 tahun. Pengalaman penelitian menunjukkan bahwa M3 akan muncul antara usia 18 hingga 30 tahun. Berdasarkan kisaran ini, 
berarti bahwa telah erupsinya M3 pada seseorang menunjukkan bahwa usia individunya telah melewati usia 18 tahun.

Formula gigi pada gigi susu (anak-anak) menunjukkan susunan : 2 incisivus, 1 canin, dan 2 molar pada setengah mandibula atas atau bawah, dengan jumlah lengkap 20 gigi. Di lain pihak, formula gigi dewasa adalah 2 incisivus, 1 canin, 2 premolar, dan 3 molar, jumlah lengkap 32 gigi. Mengingat erupsi setiap jenis gigi adalah tertentu, maka dengan melihat tingkat erupsi gigi, baik anak-anak maupun dewasa, akan diperoleh tafsiran usia individu. Beberapa contoh dapat diberikan :

- incisivus pertama anak-anak

- geraham kedua anak-anak

- geraham pertama dewasa

- geraham kedua dewasa

- geraham ketiga dewasa
: 6 bulan

5 tahun

: 6 tahun

: 12 tahun

lebih dari 18 tahun, dan sebagainya

\section{Tingkat keausan gigi}

Bagaimana seandainya individu tersebut telah mempunyai M3, yang berarti usianya lebih dari 18 tahun ? Parameter yang dapat dipakai sebagai analisis penentuan usia selanjutnya adalah tingkat keausan gigi, yang tentunya ini akan diperlakukan bagi individu dewasa, lebih dari 18 tahun. Penafsiran usia individu berdasarkan tingkat keausan ini lebih bersifat prediktif, karena meski gigi merupakan bagian paling keras dari manusia, tingkat keausannya tidak semata-mata kerena usia saja, tetapi dipengaruhi oleh berbagai faktor, misalnya jenis alimentasi (keras atau lunak), faktor kesehatan individu, dan frekwensi pemakaian. Dengan demikian, penentuan usia berdasarkan tingkat keausan gigi hanyalah merupakan teknik suplemen saja, ketika individu telah melewati usia 18 tahun.

Dalam proses hidup seseorang, jenis gigi yang paling awal akan terkena aus adalah gigi geraham. Hal ini disebabkan oleh luasnya permukaan oklusal pada jenis ini, sesuai dengan fungsinya sebagai gigi pengunyah. Hal ini berbeda dengan fungsi gigi seri untuk memotong dan gigi taring untuk merobek, yang frekwensi pemakaiannya akan lebih keeil dibandingkan dengan gigi geraham. Logikanya, gigi geraham akan lebih aus dibandingkan dengan prageraham, taring, ataupun seri. Secara ekstrim, aus gigi pada geraham dapat menunjukkan usia individu dewasa muda, tetapi aus gigi (secara alamiah) pada gigi seri akan terjadi pada individu dewasa lanjut. Sering kali ditemukan situasi ausnya gigi geraham dalam tingkat lanjut, tetapi masih mempunyai gigi seri yang utuh.

Dengan mempertimbangkan segala aspek penyebab aus di atas, maka dapat dirumuskan secara tentative korelasi antara tingkat keausan geraham dengan usia individu sebagai berikut. 
- aus pada email sebelum mencapai dentin (derajad 1) : telah melewati 35 tahun

- aus mencapai sebagian dentin (derajad 2) : telah melewati usia 45 tahun

- aus mencapai seluruh dentin (derajad 3) : telah melewati usia 60 tahun

- aus mencapai cavita pulpae (derajad 4) : telah melewati usia 60 tahun

- aus hampir menghilangkan seluruh mahkota gigi (derajad 5) : telah melewati usia 60 tahun

\section{E. Identifikasi Jenis Ras}

Hasil penelitian hingga saat ini menunjukkan adanya dua ras pokok yang sering ditemukan dalam konteks sisa rangka prasejarah, yaitu ras Austromelanesid dan Mongoloid. Ditinjau dari interpretasi migrasinya, ras Austromelanesid mulai mengokupasi kawasan Asia Tenggara sejak 10.000 tahun silam (Jacob, 1967), terutama di bagian barat dan selatan. Pada saat yang sama, ras Mongolid beremigrasi dari utara ke selatan melalui Taiwan dan Filipina, yang kemudian menghuni Indonesia bagian utara dan timur. Pada masa kemudian, sekitar 4.000 tahun yang lalu, terjadi gelombang migrasi ras Melayu yang mengenalkan budaya neolitik (Jacob, 1967), dan akhimya menghasilkan populasi manusia saat ini.

Berdasarkan pengalaman perolehan sisa rangka selama ini, tampaknya identifikasi perlu diberikan di sini adalah identifikasi ras Austromelanesid dan Mongoloid, berdasarkan perbedaan karakter morfologisnya. Secara umum, ras Austromelanesid menunjukkan postur tubuh yang lebih tinggi dan lebih kekar, dengan berbagai perbedaan yang spesifik antara keduanya. Kekekaran postur tersebut sangat tampak pada bagian kepalanya, baik yang mencakup superstruktur kranial maupun alat-alat pengunyahnya. Secara lebih spesifik, perbedaan tersebut dapat dijabarkan sebagai berikut :

\begin{tabular}{|l|l|l|}
\hline & \multicolumn{1}{|c|}{ Austramelanesid } & \multicolumn{1}{|c|}{ Mongoloid } \\
\hline bentuk tengkorak & dolichocephal & brachycephal \\
& mesocephal & \\
frontal & agak miring & relatif vertikal \\
torus supra orbitalis & ada & tidak ada \\
dinding parietal & vertikal & membundar \\
lunas sagittal & ada & tidak ada \\
depresi prelambda & ada & tidak ada \\
occipital & menonjol & tatar \\
rongga mata & rendah & dangkal \\
akar hidung & dalam & sempit dan dalam \\
langit-langi maxilla & lebar dan dalam & \\
\hline
\end{tabular}




\begin{tabular}{|c|c|c|}
\hline $\begin{array}{l}\text { bagian alveolaris } \\
\text { dibandingkan basilaris }\end{array}$ & lebih tebal & relatif sama \\
\hline $\begin{array}{l}\text { planum alveolaris } \\
\text { torus mandibularis } \\
\text { gigi geligi }\end{array}$ & $\begin{array}{l}\text { kadang ada } \\
\text { berkembang } \\
\text { besar }\end{array}$ & $\begin{array}{l}\text { tidak ada } \\
\text { tidak berkembang } \\
\text { relatif lebih kecil }\end{array}$ \\
\hline $\begin{array}{l}\text { ukuran dan bentuk } \\
\text { geraham }\end{array}$ & belum tereduksi & sudah tereduksi \\
\hline kuspid geraham & berkembang & $\begin{array}{l}\text { kadang kurang } \\
\text { berkembang }\end{array}$ \\
\hline
\end{tabular}

Ciri-ciri tersebut di atas merupakan ciri fisik yang umum dijumpai pada masingmasing ras. Terdapat di antaranya ciri-ciri yang lebih tegas seperti bentuk tengkorak antara dolicho maupun mesocephal pada ras Australomelanesid dan brachycephal pada Mongloloid, ataupun juga ciri kuat lainnya seperti dinding parietal yang reletif vertikal, depresi pre-lambdatik, maupun tonjolan pada daerah median occipital. Demikian pula, aspek prognathisme yang kuat, yang berimplikasi terhadap eksistensi alat pengunyah yang lebih berkembang, seperti bagian alveolaris mandibularis yang lebih tebal dibandingkan dengan pars basilarisnya, termasuk lebih berkembangnya gigi-geligi di kalangan ras Austromelanesid dibandingkan dengan ras Mongoloid. Selain itu, juga terdapat ciri morfologis yang terkadang ada dan terkadang tidak, yaitu eksistensi planum alveolaris maupun torus mandibularis. Dalam identifikasi jenis ras ini, penentuan akhir dilakukan melalui pengamatan secara menyeluruh, dengan mempertimbangkan aspek morfologis penentu jenis ras yang lebih dominan.

\section{F. Penutup}

Hampir pasti bahwa temuan sisa manusia dalam konteks data arkeologi di Indonesia hanya akan berkisar pada dua spesies, yaitu Homo erectus dan Homo sapiens. Secara morfologis, kedua jenis ini sangat mudah dibedakan pada aspek kranio-fasialnya, tetapi sangat sulit untuk komponen infra-kranialnya. Disebabkan oleh sifat data Homo erectus yang sangat terbatas dan sering dalam bentuk fragmentaris dan disertai dengan pentingnya pengamatan setiap aspek morfologis dari spesies ini karena mempunyai arti evolutif yang sangat berharga informasinya dalam kajian proses evolusi manusia, maka analisis yang dilakukan pada setiap temuan sisa manusia dari lingkup Homo erectus harus dilakukan secara lebih detil, lebih cermat, dan lebih teliti, untuk sampai pada setiap interpretasi yang dapat ditarik dari padanya. Secara lebih tegas, harus dikatakan di sini bahwa data dari sisa Homo erectus harus dieksploitasi semaksimal mungkin dalam proses analisisnya untuk mencapai informasi evolutif yang terdapat di dalamnya. 
Sebaliknya, sisa manusia dari lingkup Homo sapiens sebagai produk akhir dari proses evolusi manusia cukup banyak ditemukan dalam kualitas data yang jauh lebih lengkap dibandingkan Homo erectus, sehingga dapat ditawarkan variabel teknis analisis yang cukup representatif untuk setiap temuan sisa manusia dalam penelitian arkeologi. dengan sasaran analisis yang mencakup : meterial tersisa, identifikasi jenis kelamin. identifikasi usia individu, dan identifikasi ras. Dua jenis ras ditawarkan dalam analisis ini, yaitu ras Austromelanesid dan Mongoloid, sebagai ras yang paling mendominasi data arkeologi.

\section{KEPUSTAKAAN}

Broca, P., 1875. Instructions craniologiques et craniometriques, Memoir de la Societe d' Anthropologie de Paris 2, Serie II, 207 p.

Dellatre, A. et R. Fenart, 1960. L'hominisation du crane. Paris, edition du CRNS.

Handini, R., \& Widianto, H. (1998). Song Keplek: Okupasi Intensif Manusia Pada Periode Pasca-Plestosen Di Gunung Sewu. Berkala Arkeologi, 18(2), 72-91. https:// doi.org/10.30883/jba.v18i2.785

Jacob, T., 1967. Some Problems Pertaining to the Racial History of the Indonesian Region: A Study of Human Skeletal and Dental Remains from Several Prehistoric Sites in Indonesia and Malaysia. Utrecht : Drukkerij Neerlandia.

Masset, C., 1982. Estimation de I 'age au deces par Les sutures craniennes. These de Doctorat et Sciences. Paris : Universite de Paris VII.

Widianto, Harry, 1999a. Prehistoric cave dweller in Gunung Sewu, dalam Simanjuntak (editor), Gunung Sewu : Exploitation in Holocene. In-press.

Widianto, Harry, 1999b. Laporan Analisis Sisa Manusia dari Song Keplek : Individu ke-5. Jakarta : Bidang Prasejarah Pusat Penelitian Arkeologi Nasional. Belum diterbitkan.

Widianto, Harry, 1999c. Perspective on the evolution of Javanese Homo erectus : based on the morphological and stratigraphical characters, Colloqium on Sangiran : Man, Culture, and Environment in the Pleistocene. Solo : Pusat Penelitian Arkeologi Nasional, in-press. 